\title{
Proteasome Subunit Beta Type-5
}

National Cancer Institute

\section{Source}

National Cancer Institute. Proteasome Subunit Beta Type-5. NCI Thesaurus. Code C116677.

Proteasome subunit beta type-5 (263 aa, $28 \mathrm{kDa}$ ) is encoded by the human PSMB5 gene. This protein plays a role in proteasomal protein degradation. 